SHORT NOTES

\title{
NOTE ON A METEOR FALL NEAR THE ORADEA FORTRESS AT THE END OF THE XVII ${ }^{\text {th }}$ CENTURY
}

\author{
MIHAI GEORGIȚĂ ${ }^{1}$
}

\begin{abstract}
During the preparation of a new siege of the Austrian imperial army upon the Oradea fortress - still occupied by the Turks, an astronomical event was noticed by the high rank officers. At the end of a long war report forwarded by general Veterani to Emperor Leopold II on the $20^{\text {th }}$ of April 1692, a brief version of a note by general Auersperg on this meteor fall was also included. There he mentioned about a "fire ball" that was noticed in the skies on April $8^{\text {th }}$ around 10 p.m., that went beyond the blockade, fortress and the army forefront, and finally landed in the woods in the neighborhood. The note does not mention about any fragment being recovered. If the information presented above is confirmed, the fall from Oradea (1692) would represent the $11^{\text {th }}$ and at the same time the oldest meteor recorded in Romania.
\end{abstract}

Keywords: meteor fall, Oradea, Transylvania, Romania, 1692.

At the end of March - beginning of April 1692, the General who was leading the Austrian blockade against Oradea fortress, Count von Auersperg, was preparing the final siege. In the middle of these preparations, an astronomic event drew the attention and caused confusion within the troops. Several pieces of information on this natural phenomenon were included at the end of a long report on the requests for food supplies, equipment, ammunitions and other military items, as well as on the general situation of the Transylvanian battle field, sent by General Veterani to Emperor Leopold II (***, slides 696-706). Thus, the unexpected event was given an importance comparable to that required by the most urgent aspects of the war. By that time, General Veterani was the chief commander of the troops. $\mathrm{He}$ had been informed by von Auersperg that during the night of April $8^{\text {th }}$, around 10 p.m., close to the walls of Oradea fortress a fireball was observed. Veterani wrote in his report: "Among others, Count von Auersperg reported that in the day 8 of that month, around 10 of the night, at Oradea a fire sphere was seen in the skies, which after crossing the blockade, the fortress, and then our own forefront, fell in the woods over there" ( ${ }^{* * *}$, slide 707 ; in original: ..."Übrigens hat der Graff von Auersperg berichtet, dass den $8^{\text {th }}$ dieses nachts um 10 Uhr bei Waradein ein feurige Kugel an dem Himmel gesehen worde, welche sodann über unsere Schantz, die Festung und unsere Feldwachte in dem aldortige Wald gefallen seye"...). The note does not mention about any fragment being recovered.

\footnotetext{
${ }^{1}$ Direcția Județeană Bihor a Arhivelor Naționale, lancu de Hunedoara 10, Oradea, Romania.
} 
The report was sent to the Emperor, together with a sketch showing the trajectory taken by the meteor until it reached the soil, where it fragmented (Fig. 1). The sketch presents a cloudy sky during the event. Also, a shining fire track of the incandescent and multicoloured material was noticeable $\left({ }^{* * *}\right.$, slide 708$)$. By comparing the details in the sketch with a military map, drawn one month later, we may assume that the trajectory of the fall was NW-SE. In the report, the size of the object has been compared to a $200 \mathrm{~kg}$ bomb. Taking into account the relatively long distance between the observers and the place of fall, the object might have been larger.

The author of the sketch must have been General von Auersperg itself and/or his subordinates, knowing that they were eye-witnesses of the phenomenon. The event produced such an astonishment and curiosity that it was considered that the Emperor must be informed about it. No doubt, many of the high rank officers in the imperial army had been highly educated. For example, General Marsigli, several years later, performed archaeological, geographical, botanical and zoological studies on the territory of the Romanian provinces. Thus, the officers could have had a scientific approach on the astronomical event. The sketch and explanations were probably intended to serve as documentation for further scientific studies at the University in Vienna, or for scientists under the Emperor's protection, such as Tycho Brache and Johann Kepler, the founders of modern astronomy (Chaunu, 1989). The science of the XVII ${ }^{\text {th }}$ century was dominated by astronomy and its great achievements (Chaunu, 1989). However, astrology was still highly valued, by that time reaching in fact its maximum; even Kepler had performed such investigations (Drimba, 1990). At the end of the XVII ${ }^{\text {th }}$ century, astrology continued to have a strong impact on politicians and scientists (Delumeau \& Morariu, 1986). Under these circumstances, a meteor or a meteorite fall could have been considered as a "sign", either a "good", or a "bad" one. It could have indicated that the end of the Turkish domination in Bihor region (with the centre at Oradea) was getting closer, especially after a comet noticed above Oradea at the end of 1660 (Balogh, 1982) had been interpreted as the beginning of the loss of Turkish control on the area. Such an event could have led to panic, since in the medieval collective mentality a meteorite fall was considered to represent a sign of a disaster (Binder \& Cernovodeanu, 1993).

The recognition of such an event could have a special meaning for the geology and astronomy of Romania, being the oldest record of a meteor in the country. In this context, below a brief summary of the Romanian meteors and meteorite falls is presented. Until now, three meteors were known from the Romanian territory. Stanciu \& Stoicovici (1943) indicate the meteor from Târgovişte (1774) as the oldest record of this type. Based on the information in the work Auraria Romano Dacica by Samuel Kóleséri, published in Kosice (1780) about the meteor from Buzău (1714), Maxim (1968) considers this event as the first mention. According to Kóleséri, Prince Constantin Brâncoveanu sent the collected fragments to Cluj for being studied. The fragments were not recovered, and no information on their fate is known in present. The name given to the presumed "meteorite", i.e. "Magnus meteoriticus Bozaianus", suggests a relatively large size of the object. Another Romanian meteor was observed between the localities Târgu-Jiu, Gorj district, and Cogealac, Tulcea district in 1906 (Hepites, 1906). 


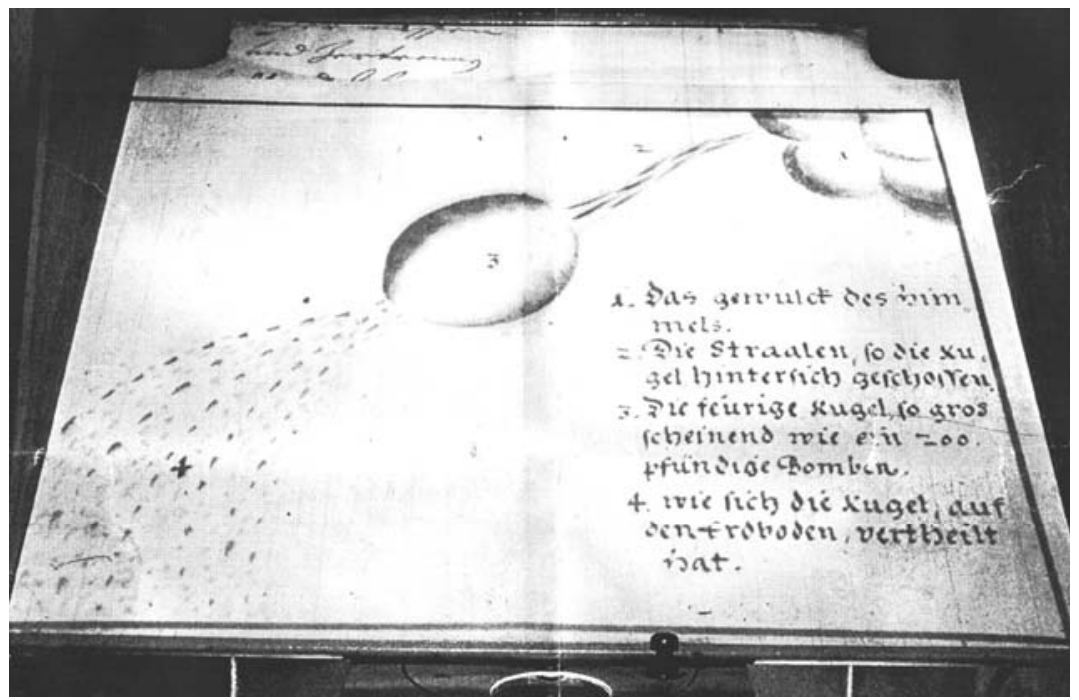

Fig. 1. The original sketch by Count Auersperg and his officers, included by General Veterani in the war report to the emperor Leopold II on April 20 ${ }^{\text {th }}$, 1692. It represents the fireball that was noticed in the skies on April $8^{\text {th }}, 1692$ around 10 p.m. near the Oradea fortress.

There are 7 meteorites (all of them ordinary chondrites) reported to be fallen in Romania (Grady, 2000). In a chronological sequence, they are named as follows: Mezö-Mădăraş (syn. Mădăraş), Mureş district (1852); Ohaba, Alba district (1857); Kakowa (syn. Cacova), Caraş-Severin district (1858); Zsadany (syn. Jadani), Timiş district (1875); Mocs (syn. Mociu), Cluj district (1882) - the largest Romanian meteorite; Sopot, Dolj district (1927); and Tăuți, Arad district (1937). Additionally, one meteoritic found was reported from Tuzla, Constanța district. The largest amount of the Mocs meteorite (1600 fragments with a total weight of $118 \mathrm{~kg}$ ) is kept in the Museum of Natural History in Vienna, while the largest Mocs meteorite fragment $(35.7 \mathrm{~kg})$ is preserved in the Mineralogical Museum of the Babeş-Bolyai University in Cluj-Napoca.

The Catalogue of Meteorites, published by the Natural History in London (Graham et al., 1985) indicates the Tăuți meteorite as being located near Oradea. In fact, as mentioned before, the Tăuți fall took place in Arad district (Hadnagy et al., 2002).

The newly identified document on the fireball near Oradea increases the number of known Romanian meteors (3) and meteorites (8, of which 7 fallen +1 found) to a total of 12 . In the same time, this record from 1692 would be the oldest, and for the moment the only one located in Bihor County. Our note is also intended to draw the attention of curators in museums outside Romania that host meteorite collection, in the view of a fortunate situation when fragments of this meteorite could be identified.

With only one exception, that of "Magnus meteoriticus Bozaianus", all the other Romanian events related to meteoroids were recorded in the western part of the country, between $19^{\circ} 34^{\prime}$ and $24^{\circ} 19^{\prime}$ east longitude. We cannot agree with Döll (in Stanciu \& Stoicovici, 1943) that the number of local meteorite fall records is 


\section{MIHAI GEORGIȚĂ}

related to the degree of civilisation of a region, which would represent an objective cause for a meteor or meteorite fall identification and documentation.

Acknowledgments. The original text was significantly improved upon the very valuable suggestions and corrections of an anonymous referee, whose expertise is greatly acknowledged. Our thanks are due to Dr. Dana Pop from the Mineralogical Museum of the "Babeş-Bolyai" University for the English translation and for some minor corrections to the text.

\section{REFERENCES}

Binder, P. \& Cernovodeanu, P. 1993, Cavalerii Apocalipsului: calamitățile naturale din trecutul României (până la 1800). Ed. Silex, Bucureşti, 255 p.

Balogh, J. 1982, Varadinum Várad Vára. Vol II, Akadémiai Kiadó, Budapest, 396 p.

Chaunu, P. 1989, Civilizația Europei clasice. Vol. II, Ed. Meridiane, Bucureşti, 376 p.

Delumeau, J. \& Morariu, M. 1986, O cetate asediată. Ed. Meridiane, Bucureşti, 361 p.

Drimba, O. 1990, Istoria culturii şi civilizației. Vol. III, Ed. Ştiințifică şi Enciclopedică, Bucureşti, $736 \mathrm{p}$.

Grady M. M. 2000, Catalogue of Meteorites; with special reference to those represented in the collection of the British Museum (Natural History), 5th ed., British Museum (Natural History), London.

Graham, A.L., Breven, A. W. \& Hutchison B. (Eds.) 1985, Catalogue of Meteorites. British Museum (Natural History), London, $460 \mathrm{p}$.

Hadnagy, A., Miura, Y., lancu, O. G. 1999, Field Survey of Spherules and Other Microminerals From the Tăuți Meteorite Fall Area (Arad County, Romania), Abstracts of the International Symposium On Planetary Impact Events And Their Consequences On Earth "PIECE'99", September 27-30, 1999, Japan, p. 34.

Hepites, Şt. C. 1906, Bolidul de la 1 ianuarie 1906. An. Acad. Rom., S II, 26: 206-210.

Köleséri S. 1780, Auraria Romano Dacica, Cassoviae, Ioan Michaelis Landerer Tipographi et Bibliopolae, 246-247.

Maxim, I.A. 1968, Meteoriți şi materiale meteoritice din România. Studia Universitatis BabeşBolyai, Seria Geologia-Geografia, 13 (1): 3-6.

Stanciu, V. \& Stoicovici, E. 1943, Meteoriții din România. Revista Muzeului MineralogicGeologic, Universitatea Cluj, 7 (1-2): 121-152.

*** Arhivele Naționale Bucureşti; Fond Austria, microfilmele 696-708. 